\title{
Synthesis and Reactions of Optically Active Cyanohydrins
}

\author{
Franz Effenberger *
}

Cyanohydrins have always held a place of importance both as technical products and as reagents in organic chemistry. It is surprising. therefore, that optically active cyanohydrins have been extensively investigated and employed for syntheses relatively recently. This can be explained by the fact that only in the past few years have enzymatic methods made chiral cyanohydrins readily available in high optical purity. Chiral cyanohydrins are widespread in nature in the form of the respective glycosides and serve roughly 3000 plants and many insects as antifeedants. For the preparative organic chemist, this class of compounds offers an enormous synthetic potential for making other chiral compounds accessible. In a few instances, the pharmacological principle of a drug also incorporates a chiral cyanohydrin as constitutive structural element. In the development of novel, physiologically active compounds all possible stereoisomers must be synthesized and investigated with respect to their activity range and the pathway of their metabolic transformations and/or degradation. The development of simple synthetic procedures for such compounds, which also entail a high degree of stereoselectivity, therefore has prime importance. To this end chiral cyanohydrins may serve as stereochemically pure starting materials.

In the present review, the following topics will be addressed: enantioselective addition of hydrogen cyanide (HCN), catalyzed by the enzymes $(R)$ and $(S)$-oxynitrilase, to aldehydes and ketones yielding $(R)$ and $(S)$ cyanohydrins, respectively; enantioselective addition of $\mathrm{HCN}$ to aldehydes catalyzed by cyclic dipeptides; enantioselective esterification of racemic cyanohydrins and enantioselective hydrolysis of cyanohydrin esters catalyzed by lipases and esterases, respectively; transformation of the nitrile group of chiral cyanohydrins to provide optically active $\alpha$-hydroxycarboxylic acids, aldehydes, and ketones, as well as 2-amino alcohols; sulfonylation of the $\mathrm{OH}$ group of chiral cyanohydrins to furnish optically active $\alpha$-sulfonyloxynitriles which undergo $\mathrm{S}_{\mathrm{N}} 2$ displacement of the activated $\mathrm{OH}$ group yielding $\alpha$-azido-, $\alpha$-amino, and $\alpha$-fluoronitriles with inverted configuration.

\section{Introduction}

A whole series of procedures has been developed in the last few years for preparing optically active cyanohydrins as precursors for $\alpha$-hydroxycarboxylic acids, $\alpha$-hydroxy aldehydes, and vicinal amino alcohols, which have thus become accessible in stereochemically pure form..$^{[1-3]}$

The stereoselective syntheses of cyanohydrins can be classified into chemical and enzymatic (enzyme-catalyzed) procedures. The most important chemical methods are the diastereoselective addition of trimethylsilyl cyanide ${ }^{[4]}$ and related cyanide-transfer agents ${ }^{[5]}$ to chiral aldehydes, and the enantioselective addition of trimethylsilyl cyanide to aldehydes in the presence of chiral catalysts. ${ }^{[6,7]}$ Enzymatic procedures leading to optically active cyanohydrins include the oxynitrilase-catalyzed enantioselective addition of $\mathrm{HCN}$ to aldehydes, the enantioselective hydrolysis of cyanohydrin ester racemates with es-

${ }^{*}{ }^{*}$ Prof. Dr. F. Effenberger

Institut für Organische Chemie der Universität

Pfaffenwaldring 55, D-70569 Stuttgart (FRG)

Telefax: Int code $+(711) 685-4269$ terases, and the enantioselective esterification of cyanohydrin racemates with lipases.

In special cases cyclic dipeptides also catalyze the enantioselective addition of $\mathrm{HCN}$ to aldehydes $;{ }^{[8]}$ this procedure does not fit into the chemical/enzymatic classification. Formally, cyclic dipeptides can be considered chiral catalysts; however, structural similarities to the active center of oxynitrilases, the structure of which is not yet known, cannot be ruled out completely.

If one weighs the advantages and disadvantages of the chemical and enzymatic methods for preparing optically active cyanohydrins, the scales tip in favor of enzyme-catalyzed processes as general techniques, both with respect to the ee values attainable and possible adaptation for the preparation of cyanohydrins on a technical scale. This does not exclude the possibility, though, that other processes might be more advantageous in special cases.

This review focuses on the enzyme-mediated procedures and the use of cyclic dipeptide catalysts for the synthesis of optically active cyanohydrins, in particular aldehyde cyanohydrins, because of their practical importance. In addition, the tremendous potential of optically active cyanohydrins for the synthesis of other important chiral compounds will be discussed. 


\section{2. (R)-Oxynitrilase-Mediated Addition of $\mathrm{HCN}$ to Aldehydes}

One of the first asymmetric synthesis effected by enzymes ("durch Enzyme bewirkte asymmetrische Synthese" ${ }^{[9]}$ ), published by L. Rosenthaler in 1908, concerns the preparation of mandelonitrile from benzaldehyde and $\mathrm{HCN}$, with emulsin as source of the enzymatic catalyst. Rosenthaler gave detailed information on the course of the reaction and the effect of the reaction conditions on the optical yield, but this interesting example of an enzyme-catalyzed asymmetric synthesis was not followed up for many years. [10]

More than fifty years later E. Pfeil et al. took up the idea and developed it into a more general procedure. The enzyme $(R)$ oxynitrilase [EC 4.1.2.10], which actually catalyzes the addition of HCN to benzaldehyde, was isolated from bitter almonds (Prunus amygdalus), purified, and characterized. ${ }^{[1]}$ It was shown that $(R)$-oxynitrilase accepts other aromatic aldehydes besides its natural substrate benzaldehyde, as well as saturated and unsaturated aliphatic and heterocyclic aldehydes; in each case, the enzyme catalyzes the formation of the corresponding (R) cyanohydrin. ${ }^{[12]}(R)$-Mandelonitrile was prepared with $86 \%$ ee (determined from the specific rotation), which was very high for that time. For less reactive aldehydes, however, the optical yield decreased dramatically; thus, this simple procedure for the preparation of $(R)$ cyanohydrins found virtually no practical application for the next two decades.

All efforts failed to improve the optical yields under the conditions used by Pfeil et al. (solvent: water or water/ethanol; $\mathrm{pH}$ 5-6 corresponding to the activity optimum of the enzyme).$^{[12 b .13 a]}$ Under these conditions the chemical addition of HCN to aldehydes leading to racemic products cannot be suppressed and prevails especially when the enzyme-catalyzed reaction is slow.

The decisive breakthrough for this process came when it was discovered that the undesirable chemical addition is more or less suppressed in organic solvents that are not miscible with water, for example ethyl acetate or diisopropyl ether (Fig. 1). ${ }^{[13]}$ As Figure 1 shows, the uncatalyzed addition of $\mathrm{HCN}$ to benzaidehyde is very slow indeed in ethyl acetate. Thus even for aldehydes that are poor substrates for the enzyme, the enzymatic process predominates over the chemical addition in these media, and products with high ee values result (see Scheme1, Table 1$){ }^{[13]}$ In contrast to most other enzyme-catalyzed reac-

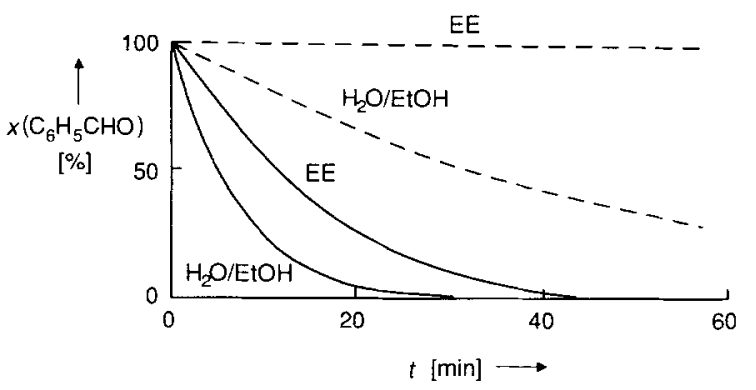

Fig. 1. Comparison of the rate of addition of HCN to benzaldehyde $(x=$ mol fraction) in $\mathrm{H}_{2} \mathrm{O}: \mathrm{EtOH}$ and in ethyl acetate (EE) without enzyme (- - ) and with enzyme (-).

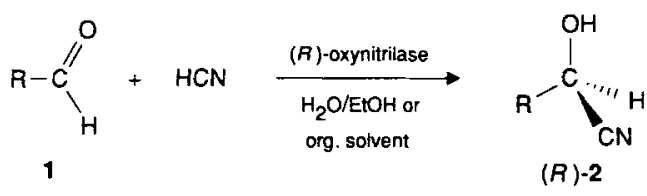

Scheme 1. Preparation of $(R)$ cyanohydrins by $(R)$-oxynitrilase-catalyzed addition of $\mathrm{HCN}$ to aldehydes.

Table 1. Synthesis of $(R)$ cyanohydrins $(R)-2$ by enzyme-catalyzed addition of HCN to aldehydes $\mathrm{I}$ in $\mathrm{H}_{2} \mathrm{O}: \mathrm{E}$ tOH and in organic solvents [13].

\begin{tabular}{|c|c|c|c|c|c|c|c|c|c|}
\hline \multirow[t]{2}{*}{$\mathrm{R}$} & \multicolumn{3}{|c|}{ in $\mathrm{H}_{2} \mathrm{O} / \mathrm{EtOH}$} & \multicolumn{3}{|c|}{ in EtOAc:Avicel [a] } & \multicolumn{3}{|c|}{ in $i \mathrm{Pr}_{2} \mathrm{O} /$ Avicel [a] } \\
\hline & $\begin{array}{l}t \\
{[\mathrm{~h}]}\end{array}$ & $\begin{array}{l}\text { Yield } \\
{[\%]}\end{array}$ & $\begin{array}{l}e e[b] \\
{[\%]}\end{array}$ & $\begin{array}{l}t \\
{[\mathrm{~h}]}\end{array}$ & $\begin{array}{l}\text { Yield } \\
{[\% / \%]}\end{array}$ & $\begin{array}{l}e e[b] \\
{[\%]}\end{array}$ & $\begin{array}{l}t \\
{[\mathrm{~h}]}\end{array}$ & $\begin{array}{l}\text { Yield } \\
{[\%]}\end{array}$ & $\begin{array}{l}e^{e}[\mathrm{~b}] \\
{[\%]}\end{array}$ \\
\hline $\mathrm{C}_{6} \mathrm{H}_{s}$ & 1 & 99 & 86 & 2.5 & 95 & 99 & 3 & 96 & $>99$ \\
\hline $3-\mathrm{C}_{6} \mathrm{H}_{5} \mathrm{O}-\mathrm{C}_{6} \mathrm{H}_{4}$ & 5 & 99 & 11 & 192 & 99 & 98 & - & - & \\
\hline 2-furyl & 2 & 86 & 69 & 4 & 88 & 99 & - & & - \\
\hline 3-thienyl & - & & $\ldots$ & -- & & - & 6 & 95 & $>99$ \\
\hline 3 -pyridyl & 2.5 & 78 & 7 & 4.5 & 89 & 14 & 3 & 97 & 82 \\
\hline $\mathrm{H}_{3} \mathrm{CCH}=\mathrm{CH}$ & 1.5 & 68 & 76 & 3 & 68 & 97 & $\cdots$ & - & \\
\hline $\mathrm{H}_{3} \mathrm{CS}\left(\mathrm{CH}_{2}\right)_{2}$ & 3 & 87 & 60 & 6.5 & 97 & 80 & 16 & 98 & 96 \\
\hline $\mathrm{C}_{3} \mathrm{H}_{2}$ & 2 & 75 & 69 & $\cdots$ & & - & 16 & 98.6 & 98 \\
\hline $\mathrm{C}_{\mathrm{n}} \mathrm{H}_{5}\left(\mathrm{CH}_{2}\right)_{3}$ & & - & & -- & - & & 45 & 94 & 90 \\
\hline$\left(\mathrm{H}_{3} \mathrm{C}\right)_{3} \mathrm{C}$ & 2.5 & 56 & 45 & 4.5 & 78 & 73 & 4.5 & 84 & 83 \\
\hline
\end{tabular}

[a] The enzymes were bound to crystalline cellulose (Avice]). [b] Determined by gas chromatography after either reaction with $(R)$ - $x$-methoxy- $\alpha$-1rifluoromethylphenylacetoyl chloride $[(R)-(+)$-MTPA chloride $]$ to provide the diastereomeric $(R)$ $(+)$-MTPA esters, or after acetylation with acetic anhydride [13]

tions, $(R)$-oxynitrilase combines low substrate specificity with high enantioselectivity; for example, it accepts aromatic and aliphatic aldehydes and converts them to the respective cyanohydrins with high enantioselectivity (Table 1). Even with sterically demanding substrates such as isopentyl aldehyde, high

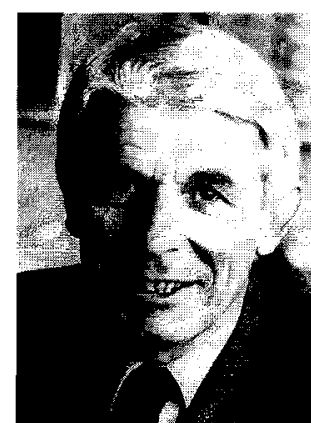

Franz Effenberger was born in 1930 in Goldenstein (North Moravia), studied chemistry from 1951 to 1956 at the Technische Hochschule in Stutgart, and received his PhD in 1959 with H. Bredereck. He completed his "Habilitation" in Stutgart in 1964 and spent a year at the University of Michigan, Ann Arbor, with P. A. S. Smith. He was a Winnacker Fellow from 1964 to 1969. In 1972 he succeded H. Bredereck at the University of Stuttgart. He was a guest professor in 1977 at Cornell University in Ithaca and in 1989 at the Ecole Supérieure de Physique et Chimie Industrielles in Paris. He received the Alexander-von-HumboldtForschungspreis in 1991. He is interested in preparative and mechanistic aspects of electron-rich $\pi$ systems (enol ethers, aminobenzenes, donor-acceptor substituted polyenes, and oligothiophenes), synthesis and reactions of $x$-amino actds, and applications of enzyme reactions in organic synthesis with emphasis on stereoselective $\mathrm{C}-\mathrm{C}$ bond formation. 
ee values $(83 \%)$ are obtained. The reaction of 3-phenoxybenzaldehyde strikingly illustrates the advantage of the organic compared to the aqueous reaction medium : the uncatalyzed reaction is suppressed to the extent that even after $192 \mathrm{~h}$ the corresponding $(R)$ cyanohydrin is obtained with $98 \%$ ee (Table 1). Only the reaction of pyridine-3-carbaldehyde gives an unsatisfactory optical yield $(14 \% e e)$ in ethyl acetate. A change of the organic medium to disopropyl ether suffices to raise the ee value once more to a satisfactory $82 \%$ (Table 1 ).

The use of organic solvents in enzyme-catalyzed reactions has been widely reported, ${ }^{[14]}$ especially for such processes where water is the actual reagent. Among these are ester-, amide-, and peptide-forming or -cleaving reactions catalyzed by lipases, amidases, and proteases. ${ }^{[14]}$ Water does not actually take part in the $(R)$-oxynitrilase-catalyzed cyanohydrin formation, but it probably promotes the chemical addition of HCN to the carbonyl double bond.

Of the many organic solvents that have been tested for oxynitrilase-mediated reactions, ${ }^{[15]}$ diisopropyl ether has proven especially advantageous with respect to the ee values obtained. This is illustrated strikingly by a number of reactions listed in Table 1 which were carried out in both ethyl acetate and diisopropyl ether. Moreover, enzyme activity in diisopropyl ether can be maintained even over a period of several weeks (Fig. 2). In ethyl acetate, in contrast. $(R)$-oxynitrilase activity is diminished by more than $50 \%$ within a few hours (Fig. 2). The lower water content in diisopropyl ether compared to that in ethyl acetate $^{[16]}$ apparently affects both $(R)$-oxynitrilase activity and stability very favorably.

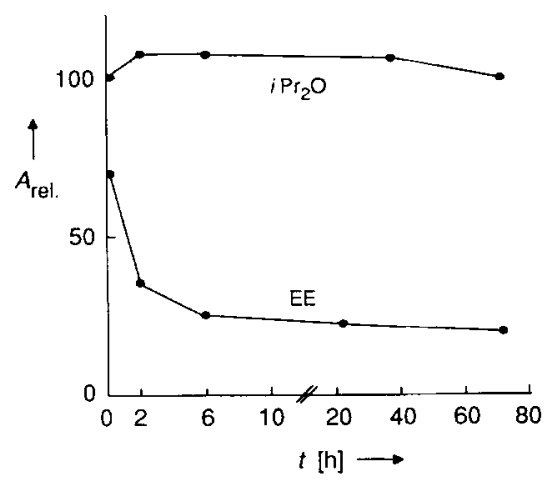

Fig. 2. Plot of the relative activity $A$ of $(R)$-oxynitrilase on a crystalline cellulose support (Avicel) in ethyl acelate (EE) and diisopropyl ether $\left(\mathrm{P}_{2} \mathrm{O}\right)$ [15].

For the reactions carried out in organic solvents it is particularly advantageous to employ enzymes bound to a suitable support, for example a crystalline cellulose material such as Avicel. Thus, the "support-bound" enzyme may be filtered off after the reaction is complete and reused as catalyst. $(R)$-Oxynitrilase in organic solvents also accepts rather high substrate concentrations (up to $2 \mathrm{~mol} \mathrm{~L}^{-1}$ ) without decreasing the ee values; thus, product formation is characterized by a highly favorable spacetime yield. ${ }^{[16]}$ The reaction may even be run in a continuous mode: the starting materials are dissolved in the organic solvent and then passed over a column loaded with the support-bound enzyme. ${ }^{[15 a]}$ or alternatively, kept in a membrane reactor whence the products are separated from unreacted starting materials and the catalyst by evaporation. ${ }^{[15 b]}$

In aqueous medium the oxynitrilase-catalyzed addition of $\mathrm{HCN}$ to aldehydes may be carried out with high selectivity also by simply lowering the $\mathrm{pH}$ of the reaction medium below 4.0, where the chemical addition is largely suppressed. ${ }^{[17]}$ Enzyme activity, however, is also reduced at such low $\mathrm{pH}$ values. This may be compensated for by employing higher enzyme concentrations; still, reactions with the less reactive aldehyde substrates have poor selectivity. Also, this process is not conductive to the reaction of aldehydes that are poorly or not at all soluble in water.

Many attempts have been reported to avoid the use of the highly toxic, free hydrogen cyanide in the synthesis of cyanohydrins. For instance, aldehydes in water/ethanol have been treated with potassium cyanide and acetic acid in the presence of $(R)$-oxynitrilase; the respective $(R)$ cyanohydrins were obtained, though with lower optical yields. ${ }^{[18]}$ Transcyanation with acetone cyanohydrin as $\mathrm{HCN}$ donor in the presence of $(R)$-oxynitrilase has been reported to give $(R)$ aldehyde cyanohydrins and acetone ${ }^{[19]}$ however, the selectivities claimed by the authors could not be reproduced. ${ }^{[20]}$

\section{3. (S)-Oxynitrilase-Mediated Addition of HCN to Aldehydes}

An enzyme that preferentially cleaves $(S)$ cyanohydrins into aldehydes and $\mathrm{HCN}$, and thus may also be expected to catalyze the reverse reaction, was first isolated from Sorghum bicolor and characterized by Conn and Bové in 1961. [21al This $(S)$-oxynitrilase [EC 4.1.2.11] and the ( $R$ )-oxynitrilase [EC 4.1.2.10] from bitter almonds differ in both structure ${ }^{[11 b, 21 b, 22]}$ and catalytic properties. The most striking structural difference is that $(R)$ oxynitrilase has a prosthetic group (flavine adenine dinucleotide, FAD) which is missing in (S)-oxynitrilase. Removal of the FAD moiety from the $(R)$-oxynitrilase results in complete loss of the catalytic activity.

It is substantially more time-consuming to isolate amounts of $(S)$-oxynitrilase sufficient for preparative purposes from Sorghum bicolor than it is to isolate $(R)$-oxynitrilase from bitter almonds. Consequently, this enzyme has been applied in organic syntheses only very recently. ${ }^{\text {[23. 24] }}$

(S)-Oxynitrilase from Sorghum catalyzes exclusively addition of $\mathrm{HCN}$ to aromatic and heteroaromatic aldehydes to yield the respective $(S)$ cyanohydrins (Scheme 2), but it does not accept aliphatic aldehydes as substrates. ${ }^{[23,24]}$ The selectivities in organic solvents are comparable for the two enzymes (Tables 1, 2).

For the synthesis of $(S)$ cyanohydrins, reactions in organic solvents rather than in aqueous medium are particularly advantageous since much smaller amounts of the poorly accessible

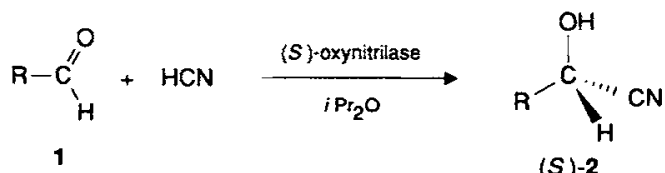

Scheme 2. Preparation of (S) cyanohydrins 
Table 2. Synthesis of $(S)$ cyanohydrins $(S)$-2 by enzyme-catalyzed addition of HCN to aldehydes 1 in diisopropyl ether [23].

\begin{tabular}{|c|c|c|c|c|c|c|c|}
\hline \multirow[t]{2}{*}{$\mathrm{R}$} & \multicolumn{3}{|c|}{ (S) Cyanohydrin 2} & \multirow[t]{2}{*}{$\mathrm{R}$} & \multicolumn{3}{|c|}{$(S)$ Cyanohydrin 2} \\
\hline & $\begin{array}{l}t \\
{[\mathrm{~h}]}\end{array}$ & $\begin{array}{l}\text { Yield } \\
{[\%]}\end{array}$ & $\begin{array}{l}e^{e}[\mathrm{a}] \\
{[\%]}\end{array}$ & & $\begin{array}{l}t \\
{[\mathrm{~h}]}\end{array}$ & $\begin{array}{l}\text { Yield } \\
{[\%]}\end{array}$ & $\begin{array}{l}e^{j}[\mathrm{a}] \\
{[\%]}\end{array}$ \\
\hline $\mathrm{C}_{6} \mathrm{H}_{5}$ & 3 & 91 & 97 & $3-\mathrm{F}_{3} \mathrm{CC}_{6} \mathrm{H}_{4}$ & 20 & 87 & 52 \\
\hline $4-\mathrm{ClC}{ }_{n} \mathrm{H}_{4}$ & 48 & 87 & 54 & $3-\mathrm{H}_{3} \mathrm{COC}_{6} \mathrm{H}_{4}$ & 20 & 93 & 89 \\
\hline $4-\mathrm{H}_{3} \mathrm{CC}_{n} \mathrm{H}_{4}$ & 32 & 78 & 87 & $3-\mathrm{C}_{6} \mathrm{H}_{5} \mathrm{OC}_{6} \mathrm{H}_{4}$ & 144 & 93 & 96 \\
\hline $3-\mathrm{HOC}_{6} \mathrm{H}_{4}$ & 24 & 97 & 91 & 2-furyl & 9 & 80 & 80 \\
\hline $3-\mathrm{BrC}_{4}, \mathrm{H}_{4}$ & 18 & 94 & 92 & 3-1hienyl 20 & 85 & 97 & \\
\hline $3-\mathrm{CK}_{8} \mathrm{H}_{+}$ & 48 & 95 & 91 & & & & \\
\hline
\end{tabular}

[a] Determined by gas chronatography of the (R)-MTPA esters as described in Talble 1.

enzyme are required. In addition some technically interesting $(S)$ cyanohydrins, such as those from 3-phenoxybenzaldehyde and various heteroaromatic aldehydes, are difficult to prepare in an aqueous system owing to the low solubility of the respective aldehydes. ${ }^{[24]}$

Recently, the catalytic activity of another $(S)$-oxynitrilase, isolated from the leaves of the rubber plant (Hevea brasiliensis), was investigated. ${ }^{[25]}$ In contrast to $(S)$-oxynitrilase from Sorghum, this enzyme was found to accept both aliphatic and aromatic aldehydes; however, the enantioselectivity of the reaction proved to be unsatisfactory for a number of substrates tested. ${ }^{[25]}$

Despite all improvements in the isolation of $(S)$-oxynitrilase from Sorghum bicolar L., ${ }^{[26]}$ industrial application of this enzyme requires the respective gene to be cloned in pro- or eucaryotic organisms and overexpressed. So far, $90 \%$ of the native hydroxynitrile lyase (HNL) has in fact been cloned. ${ }^{[26 \mathrm{~b}]}$

\section{4. ( $R$ )-Oxynitrilase-Mediated Addition of $\mathrm{HCN}$ to Ketones}

The few optically active ketone cyanohydrins described in the literature have as a rule been obtained by stereoselective addition of $\mathrm{HCN}$ or of cyanides to ketones that already have a stereogenic center. Thus, addition of $\mathrm{HCN}$ to 17 -oxosteroids proceeds with very high diastereoselectivity. ${ }^{[27]}$ Comparable optical induction is observed for the addition of $\mathrm{Me}_{2} \mathrm{Si}(\mathrm{CN})_{2}$ to chiral $\beta$-hydroxyketones, ${ }^{[28]}$ of $\mathrm{Et}_{2} \mathrm{AlCN}$ to chiral $\beta$-ketosulfoxides, ${ }^{[29]}$ and of trimethyl-(2-propenyl)silane to chiral acyl cyanides. ${ }^{[30]}$ The enantioselective hydrolysis of racemic esters of cyanohydrins with yeast cells from Pichia miso gives only poor chemical yield. ${ }^{[31]}$

The defense mechanism in which $\mathrm{HCN}$ is released from $O$-glycosyl cyanohydrins (cyanogenesis) by enzymes, is effective with both aldehyde and ketone cyanohydrins; ${ }^{[32]}$ thus, ketones are likewise expected to be substrates for oxynitrilases. For the $(R)$-oxynitrilase from bitter almonds [EC 4.1.2.10] the natural substrate is benzaldehyde; surprisingly, this enzyme also catalyzes the addition of HCN to ketones (Scheme 3), ${ }^{[33]}$ and $(R)$ cyanohydrins are formed from 2-alkanones in good chemical yield and with excellent ee values. ${ }^{[3 a]} 3$-Alkanones are much less suitable substrates; the respective cyanohydrins are obtained only with unsatisfactory chemical yield and also much lower optical purity (Table 3). ${ }^{[33]}$ The best results for the synthesis of $(R)$ ketone cyanohydrins are again obtained in organic
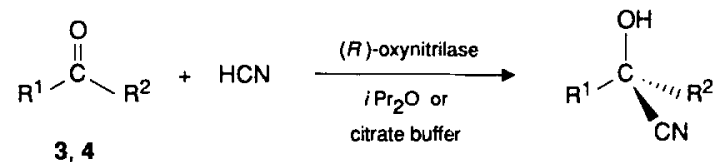

(R) $-5,(R)-6$

$$
\begin{aligned}
& 3,5: R^{1}=\text { alkyl }, R^{2}=C_{3} \\
& 4,6: R^{1}=\text { alkyl, } R^{2}=C_{2} H_{5}
\end{aligned}
$$

Scheme 3. Preparation of $(R)$ ketone cyanohydrins.

Table 3. Synthesis of $(R)$ ketone cyanohydrins $(R)-5\left(\mathrm{R}^{2}=\mathrm{CH}_{3}\right)$ and $(R)-6$ $\left(\mathrm{R}^{2}=\mathrm{C}_{2} \mathrm{H}_{5}\right)$ by enzyme-catalyzed addition of HCN to ketones $3\left(\mathrm{R}^{2}=\mathrm{CH}_{3}\right)$ and $4\left(\mathrm{R}^{2}=\mathrm{C}_{2} \mathrm{H}_{5}\right)$, respectively, in diisopropyl ether [33a] and in aqueous citrate buffer

\begin{tabular}{|c|c|c|c|c|c|c|}
\hline \multirow[t]{3}{*}{$\mathrm{R}^{1}$} & \multicolumn{4}{|c|}{ in $i \operatorname{Pr}_{2} \mathrm{O} /$ Avicel [a] } & \multirow{2}{*}{\multicolumn{2}{|c|}{$\begin{array}{l}\text { in citrate buffer [b] } \\
(R)-5[\mathrm{c}]\end{array}$}} \\
\hline & \multicolumn{2}{|c|}{$(R)-5[\mathrm{c}]$} & \multicolumn{2}{|c|}{$(R)-6[\mathrm{~d}]$} & & \\
\hline & $\begin{array}{l}\text { Yield } \\
{[\%]}\end{array}$ & $\begin{array}{l}e q \\
{[\%]}\end{array}$ & $\begin{array}{l}\text { Yield } \\
{[\%]}\end{array}$ & $\begin{array}{l}e \% \\
{[\%]}\end{array}$ & $\begin{array}{l}\text { Yield } \\
{[\%]}\end{array}$ & {$[\%]$} \\
\hline$n \mathrm{C}_{3} \mathrm{H}_{7}$ & 70 & 97 & 33 & 85 & 78 & 95 \\
\hline${ }_{n} \mathrm{C}_{4} \mathrm{H}_{4}$ & 90 & 98 & 21 & 90 & 94 & 98 \\
\hline$n \mathrm{C}_{5} \mathrm{H}_{11}$ & 88 & 98 & 7 & 66 & 56 & 96 \\
\hline$\left(\mathrm{H}_{3} \mathrm{C}\right)_{2} \mathrm{CHCH}_{2}$ & 57 & 98 & - & - & 40 & 98 \\
\hline
\end{tabular}
[33b].

[a] $20 \mathrm{U}$ enzyme per mmol ketone. [b] $50 \mathrm{U}$ enzyme per mmol ketone. $[c]$ Enantiomeric excesses of the diastereomeric $(R)$ - or $(S)$-MTPA esters determined by gas chromatography [33]. [d] Enantiomeric excesses determined by gas chromatography on $\beta$-cyclodextrin columns after saponification to give the corresponding carboxylic acids and esterification with diazomethane [33b].

solvents; the ee values for reactions in citrate buffer ( $\mathrm{pH} \leq 4)$ are comparable if at least double the amount of enzyme is employed (Table 3). ${ }^{[33 \mathrm{~b}]}(S)$-Oxynitrilase from Sorghum bicolor does not accept ketones as substrates. ${ }^{[24]}$

\section{Cyclodipeptides as Catalysts for the Enantioselective Addition of HCN to Aldehydes}

Inoue et al. showed that cyclic dipeptides (1,4-dioxopiperazines) containing a histidine moiety also catalyze the asymmetric addition of $\mathrm{HCN}$ to benzaldehyde to provide optically active mandelonitrile. ${ }^{[8,34]}$ The highest selectivity $(87 \%$ ee of $(R)$ mandelonitrile) was obtained with the cyclic dipeptide from $(S)$ histidine and $(S)$-phenylalanine (Table 4$).{ }^{[34 \mathrm{c}]}$ The reaction is not restricted to benzaldehyde. It has been extended to other aromatic aldehydes and numerous heterocyclic and aliphatic aldehydes; in most cases, though, the selectivity was unsatisfactory (Table 5). ${ }^{[34 c, 35,36]}$ With ketones, the corresponding cyanohydrins are obtained with very low enantioselectivi-

Table 4. Cyclic dipeptides as catalysts for the enantioselective addition of HCN to

\begin{tabular}{|c|c|c|c|c|}
\hline \multirow[t]{2}{*}{ Catalyst } & \multicolumn{3}{|c|}{ Mandelonitrile } & \multirow[t]{2}{*}{ Ref. } \\
\hline & Yield $[\%]$ & Config. & $e[\%]$ & \\
\hline $\operatorname{crclo}[(S)-\mathrm{Ala}-(S)-\mathrm{His}]$ & 50 & $R$ & 9.9 & {$[8 \mathrm{a}, 34 \mathrm{a}]$} \\
\hline$c k l o[(R)$-Ala-(S)-His $]$ & 90 & $R$ & 7.5 & {$[8 \mathrm{a}, 34 \mathrm{a}]$} \\
\hline $\operatorname{colo}[(S)-\mathrm{His}-(S)-\mathrm{His}]$ & 50 & $R$ & 2.5 & {$[8 \mathrm{a}, 34 \mathrm{a}]$} \\
\hline (Helo[(S)-His-(S)-Leu] & 85 & $S$ & 55 & {$[34 b]$} \\
\hline (1)lol $(S)$-His- $(S)$-Phel & 40 & $R$ & 90 & {$[8 \mathrm{~b}]$} \\
\hline $\operatorname{cyclo}(S)$-His-(S)-Phe] & 97 & $R$ & 97 & {$[34 \mathrm{c}]$} \\
\hline clclo[( $R)$-His-(R)-Phe] & 86 & $S$ & 79 & {$[36 a]$} \\
\hline
\end{tabular}
benzaldehyde. 
Table 5. Enantioselective addition of HCN to aldehydes I catalyzed by crelo[ $(S)$ His- $(S)$-Phel to give $(R)$ cyanohydrins $(R)-2$

\begin{tabular}{|c|c|c|c|c|c|c|c|}
\hline \multirow[t]{2}{*}{$\mathrm{R}$} & \multicolumn{2}{|c|}{$(R)-2$} & \multirow[t]{2}{*}{ Ref. } & \multirow[t]{2}{*}{$\mathrm{R}$} & \multicolumn{2}{|c|}{$(R)-2$} & \multirow[t]{2}{*}{ Ref. } \\
\hline & $\begin{array}{l}\text { Yield } \\
{\left[\begin{array}{c}0 \\
0\end{array}\right]}\end{array}$ & $\begin{array}{l}c e \\
{[\%]}\end{array}$ & & & $\begin{array}{l}\text { Yield } \\
{[\%]}\end{array}$ & $\begin{array}{l}e e \\
{[\%]}\end{array}$ & \\
\hline $3-\mathrm{C}_{6} \mathrm{H}_{5} \mathrm{OC}_{6} \mathrm{H}_{4}$ & 97 & 92 & {$[34 c]$} & $4-\mathrm{F}_{3} \mathrm{CC}_{6} \mathrm{H}_{4}$ & 90 & 80 & {$[36 b]$} \\
\hline $2-\mathrm{H}_{3} \mathrm{COC}_{6} \mathrm{H}_{4}$ & 45 & 84 & {$[34 \mathrm{c}]$} & $4-\left(\mathrm{C} \mathrm{H}_{3}\right)_{2} \mathrm{NC}_{6} \mathrm{H}_{4}$ & 50 & 53 & {$[36 \mathrm{~b}]$} \\
\hline $3-\mathrm{H}_{3} \mathrm{COC}_{6} \mathrm{H}_{4}^{4}$ & 97 & 90 & {$[36 \mathrm{~b}]$} & 2-naphthyl & 100 & 86 & {$[36 \mathrm{~b}]$} \\
\hline $4-\mathrm{H}_{3} \mathrm{COC}_{6} \mathrm{H}_{4}$ & 85 & 83 & [36 b] & 2-furyl & 76 & 93 & [36 b] \\
\hline $4-\mathrm{H}_{3} \mathrm{CC}_{4} \mathrm{H}_{4}$ & 91 & 92 & {$[36 \mathrm{~b}]$} & 2-pyrrolyl & 31 & 0 & {$[36 \mathrm{~b}]$} \\
\hline $4-\mathrm{O}_{2} \mathrm{NC}_{6} \mathrm{H}_{4}$ & 77 & 29 & {$[36 \mathrm{~b}]$} & 2-thienyl & 70 & 58 & {$[36 \mathrm{~b}]$} \\
\hline $3-\mathrm{HOC}_{t_{1}} \mathrm{H}_{+}$ & 75 & 67 & [35b] & 3-pyridyl & 89 & 0 & [36b] \\
\hline $4-\mathrm{HOC}_{6} \mathrm{H}_{4}$ & 86 & 35 & {$[36 b]$} & $\mathrm{C}_{3} \mathrm{H}_{7}$ & 100 & 26 & [36b] \\
\hline $4-\mathrm{ClC}_{6} \mathrm{H}_{4}$ & 96 & 66 & {$[36 \mathrm{~b}]$} & $\mathrm{C}_{6} \mathrm{H}_{5} \mathrm{CH}_{2}$ & 100 & 14 & {$[36 \mathrm{~b}]$} \\
\hline $4-\mathrm{NCC}_{n} \mathrm{H}_{+}$ & 100 & 32 & [34c] & $\left(\mathrm{H}_{1} \mathrm{C}_{2} \mathrm{CH}\right.$ & 79 & 71 & [34c] \\
\hline $4-\mathrm{C}_{0} \mathrm{H}_{5} \mathrm{OC}_{t_{2}} \mathrm{H}_{4}$ & 100 & 81 & {$[36 \mathrm{~b}]$} & $\because-\mathrm{C}_{6} \mathrm{H}_{11}$ & 96 & 58 & {$[34 c]$} \\
\hline
\end{tabular}

ties. ${ }^{[36 b]}$ In virtually all cases examined so far, cyclic dipeptide catalysts with $(S, S)$ configuration favor the formation of $(R)$ cyanohydrins. Only with cyclo[(S)-His- $(S)$-Leu $]$ are $(S)$ cyanohydrins formed preferentially. ${ }^{[34 \mathrm{~b}]}$ The dipeptide catalyst cyclo $[(R)$-His- $(R)$-Phe $]$ gives an excess of the $(S)$ product, the respective $\operatorname{cyclo}[(S)$-His- $(S)$-Phe] an excess of the $(R)$ cyanohydrin (Table 4$).^{[36 a]}$ This possibility of inverting the product configuration by simply changing the catalyst was employed in the synthesis of $(S)$-3-phenoxybenzaldehyde cyanohydrin, ${ }^{[36.37]}$ the alcohol component of a commercially important pyrethroid. $^{[38]}$

The mechanism of the enantioselective addition of $\mathrm{HCN}$ to aldehydes under cyclic dipeptide catalysis still remains to be unraveled. Nothing definite is known yet, for instance, of the structure of the transition state or of intermediates, despite many efforts. [36a. 39]

Acyclic dipeptides also show limited catalytic activity for enantioselective HCN addition to aldehydes; however, acceptable selectivities were obtained only in the presence of certain titanium complexes. ${ }^{[40]}$

\section{Preparation of $(R)$ and $(S)$ Cyanohydrins by Kinetic Resolution with Esterases and Lipases}

Aldehyde cyanohydrins are secondary alcohols and thus may form esters with carboxylic acids. Esterase-catalyzed hydrolysis or lipase-catalyzed esterification thus might be utilized to separate the enantiomers of either racemic cyanohydrins or cyanohydrin esters. ${ }^{[41]}$

\subsection{Enantioselective Hydrolysis of Racemic Cyanohydrin Esters}

If saponification of cyanohydrin acetate racemates catalyzed by ester hydrolases from Pseudomonas $s p$. is carried out in a phosphate buffer at $\mathrm{pH} 7$, only the unreacted cyanohydrin acetates are isolated in stereochemically pure form. Under the reaction conditions the chiral cyanohydrins apparently are racemized. ${ }^{[42]}$ Only in a few cases are the free cyanohydrins isolated as more or less pure enantiomers. ${ }^{[43]}$ Hydrolysis with lipases in a sodium acetate buffer at $\mathrm{pH} 4.5$ without exception affords both cyanohydrin esters and cyanohydrins in optically active form. ${ }^{411}$ Lipases from Pseudomonas fluorescens (A), lipase PS (B) and lipase P (C), preferentially cleave the $(S)$ cyanohydrin acetates; with lipases from Candida cylindracea (D) and with lipase AY $(\mathbf{E})$, on the other hand, the $(R)$ cyanohydrins are formed (Scheme 4$){ }^{[41]}$ For the lipases $\mathbf{A}, \mathbf{B}$, and $\mathbf{C}$, aromatic

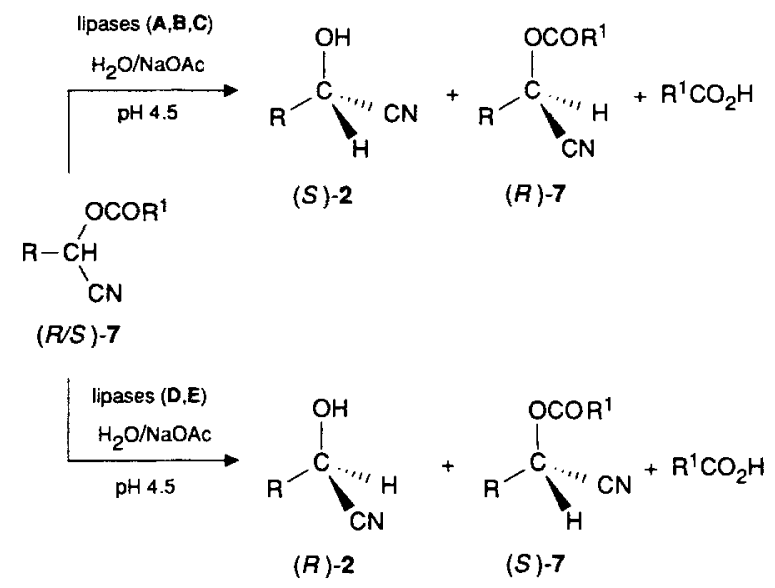

Scheme 4. Enantioselective hydrolysis of racemic cyanohydrin esters $\left(\mathrm{R}=\mathrm{C}_{3} \mathrm{H}_{7}\right.$. $\left.\mathrm{C}_{6} \mathrm{H}_{5} ; \mathrm{R}^{1}=\mathrm{CH}_{3}, \mathrm{C}_{3} \mathrm{H}_{7}, \mathrm{C}_{5} \mathrm{H}_{11}, \mathrm{C}_{6} \mathrm{H}_{5} \mathrm{CH}_{2}\right)$ with various lipases to give $(R)$ cyanohydrins and $(S)$ cyanohydrin esters, and $(S)$ cyanohydrins and $(R)$ cyanohydrin esters; lipase from Pseudomonas fluorescens (A), lipase PS (B). lipase P (C). lipase from Candida cylindracea (D), and lipase AY (E).

cyanohydrin esters are good substrates $\left(\mathrm{R}=\mathrm{C}_{6} \mathrm{H}_{5}\right)$, but aliphatic derivatives $\left(\mathrm{R}=\mathrm{C}_{3} \mathrm{H}_{7}\right)$ are not. Butyrates $\left(\mathrm{R}^{1}=\right.$ $\mathrm{C}_{3} \mathrm{H}_{7}$ ) yield $(S)$ cyanohydrins with the highest selectivities $(97 \%$ $e e)$. The situation is reversed for lipases $\mathbf{D}$ and $\mathbf{E}$; for these enzymes, the aliphatic cyanohydrin esters $\left(\mathrm{R}=\mathrm{C}_{3} \mathrm{H}_{7}\right)$ are good substrates, and the butyrates $\left(\mathrm{R}^{1}=\mathrm{C}_{3} \mathrm{H}_{7}\right)$ once again give $(R)$ cyanohydrins with the highest selectivities (up to $86 \% \ell e$ ).

\subsection{Enantioselective Esterification of Cyanohydrin Racemates}

Chiral cyanohydrins do not racemize to any significant extent in organic solvents. Lipase-catalyzed enantioselective esterification of a cyanohydrin racemate in organic solvents thus appears especially suitable for racemate resolution when the unprotected optically active cyanohydrin is desired.$^{[41,43]}$ With vinyl acetate, for which acylation is not reversible, ${ }^{[44]}$ and in dichloromethane as solvent, ${ }^{[41]}$ the lipases $\mathbf{A}-\mathbf{D}$ exhibit the same configurational specificity as that observed in the enantioselective hydrolysis of the ester racemates described in Section 6.1 (Scheme 5).

The highest optical yields for the $(S)$ acetates $(S)-7$, up to $98 \%$ ee, for aromatic cyanohydrins have been obtained with Pseudomonas fluorescens lipase (A),${ }^{[41]}$ which also catalyzes the acetylation of aliphatic cyanohydrins yielding the acetates $(S)-7$.

One principal disadvantage of kinetic resolution is that at most $50 \%$ of the racemic material can be obtained as the desired enantiomer. It is generally necessary, therefore, to subsequently racemize the remaining undesired enantiomer and to return the resulting racemate to the process. The enantioselective acetylation of a cyanohydrin racemate may also be carried out with 


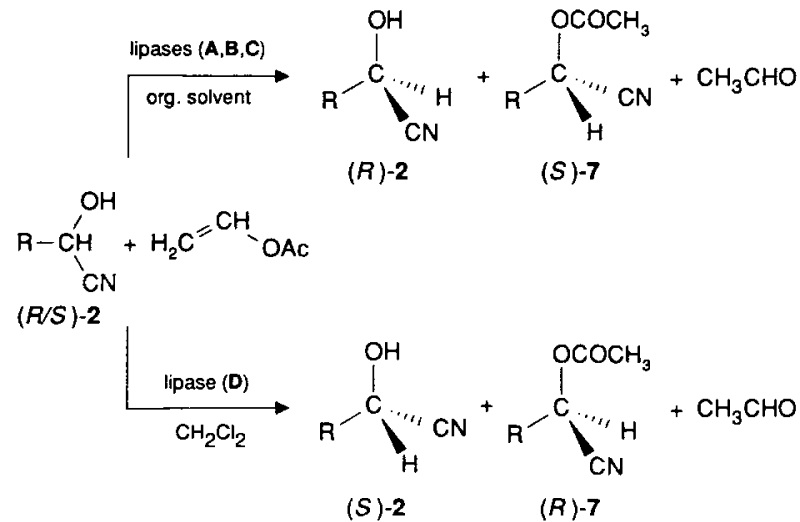

Scheme 5. Enantioselective esterification of cyanohydrin racemates $\left(\mathrm{R}=\mathrm{C}_{3} \mathrm{H}_{2}\right.$ $\mathrm{C}_{6} \mathrm{H}_{5}, \mathrm{C}_{6} \mathrm{H}_{5} \mathrm{CH}_{2} \mathrm{CH}_{2}, 4-\mathrm{HOC}_{6} \mathrm{H}_{4}, 3-\mathrm{C}_{3} \mathrm{OC}_{6} \mathrm{H}_{4}$, etc. with vinyl acetate in organic solvents with various lipases (cf. Scheme 4).

isopropenyl acetate in an organic solvent and in the presence of a basic ion exchange resin that is sufficiently basic to cause racemization of the cyanohydrin, but not of the optically active cyanohydrin acetate formed. ${ }^{[45}$ Thus, a subsequent, separate racemization is no longer required, and the racemic substrate can be completely converted into one enantiomer. The subsequent hydrolysis of the enantiomerically pure cyanohydrin acetates can be conducted under nonracemizing conditions.

Apart from the enantioselective hydrolysis of cyanohydrin ester racemates (Section 6.1) and the enantioselective esterification of such racemic cyanohydrins (Section 6.2), racemic mixtures of cyanohydrin esters can be resolved by lipase-catalyzed transesterification with high-boiling alcohols in organic solvents. $[41,46]$

\section{Stereoselective Reactions of Optically Active Cyanohydrins}

Since chiral cyanohydrins as $\alpha$-substituted carboxylic acid derivatives have considerable synthetic potential, subsequent stereoselective reactions should lead to other important classes of compounds with stereogenic centers. Two types of reactions of cyanohydrins can be differentiated: reactions of the $\mathrm{CN}$ function which do not involve the $\alpha$-hydroxyl moiety, and those in which reaction occurs at the $\mathrm{OH}$ group. Application of either reaction type in general synthesis requires racemization-free processes.

\subsection{Reactions of the Nitrile Group}

In contrast to $x$-amino acids, only a few optically active $x$-hydroxycarboxylic acids are found in nature. General processes for the preparation of chiral $\alpha$-hydroxycarboxylic acids therefore had to be developed. Today, they are accessible by straightforward chemical synthesis, ${ }^{[4]}$ by fermentation, ${ }^{[48]}$ and by enzymatic processes. ${ }^{[49,50]}$ Specific $(S) x$-hydroxycarboxylic acids may be obtained by diazotization of natural $\mathrm{L} \alpha$-amino acids in aqueous medium. The diazonium salts formed initially undergo intramolecular substitution to the respective $x$-lactones with inversion of configuration; these are hydrolyzed, again with inversion, to give $\alpha$-hydroxycarboxylic acids with a configuration identical to that of the starting $\alpha$-amino acid. The $(S)$ enantiomers thus obtained may be converted into the corresponding $(R)$-2-hydroxycarboxylic acids by activation of the $\mathrm{OH}$ group followed by $\mathrm{S}_{\mathrm{N}} 2$ displacement with an oxygen nucleophile. ${ }^{[51]}$

The racemization-free hydrolysis of chiral cyanohydrins offers an interesting general route to $(R)$ and $(S)$ 2-hydroxycarboxylic acids. Hydrolysis of an optically active cyanohydrin with concentrated hydrochloric acid was first described for mandelonitrile where it was used to probe for the optical purity of the nitrile. ${ }^{[10 a]}$ Other authors later on assumed that in some cases acid-catalyzed hydrolysis of unprotected cyanohydrins resulted in partial racemization. ${ }^{[31.35 a]}$ O-protected cyanohydrins, on the other hand, are hydrolyzed with a high degree of retention of configuration to the respective $x$-hydroxycarboxylic acids in both acidic $^{[521}$ and basic media. ${ }^{[44]}$ Since both the formation of a cyanohydrin and its cleavage to the aldehyde and HCN are base catalyzed, one might expect that the acid-catalyzed hydrolysis of unprotected cyanohydrins would proceed without racemization.

$(R)$ and $(S)$ cyanohydrins derived from aldehydes ${ }^{[13 c, 23]}$ and $(R)$ ketone cyanohydrins ${ }^{[33]}$ are indeed hydrolyzed by concentrated hydrochloric acid to give the corresponding $(R)$ and $(S)$ hydroxycarboxylic acids, respectively, in excellent chemical yield and with complete retention of configuration (Schemes 6 , 7; Tables 6,7). Actually, such hydrolyses can be carried out quite simply. In the first step, the optically active cyanohydrins are prepared from the parent carbonyl compound and HCN in an organic solvent under enzyme catalysis. The Avicel-bound enzyme is filtered off, the solvent removed, and the cyanohydrin residue hydrolyzed with concentrated hydrochloric acid directly and without any additional purification step. The $\mathrm{HCl}$ is removed, and the $x$-hydroxycarboxylic acids are extracted with

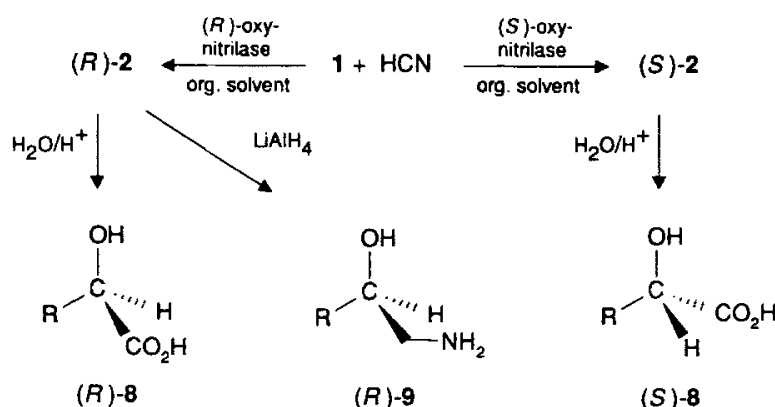

Scheme 6. Acid-catalyzed hydrolysis of $(R)$ and $(S)$ cyanohydrins to give $(R)$ and (S) 2-hydroxycarboxylic acids. respectively, and racemization-free hydrogenation of $(R)$ cyanohydrins to give $(R) 2$-amino alcohols

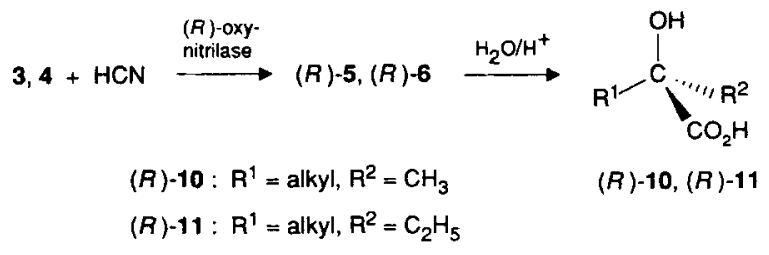

Scheme 7. Acid catalyzed hydrolysis of $(R)$ ketone cyanohydrins to give $(R)$ 2-hydroxycarboxylic acids. 
Table 6. Acid-catilyzed hydrolysis of the $(R)$ and $(S)$ cyanohydrins 2 [a] (prepared in situ by enzyme-catalyzed addition of HCN to aldehydes 1$)$ to give $(R)$ and $(S)$ $x$-hydroxycarboxylic acids 8 , respectively.

\begin{tabular}{|c|c|c|c|c|c|c|}
\hline \multirow[t]{2}{*}{$\mathrm{R}$} & \multirow{2}{*}{$\begin{array}{l}(R)-2 \\
\% \\
{[\%]}\end{array}$} & \multirow{2}{*}{$\begin{array}{l}(S)-2 \\
e c \\
{[\%]}\end{array}$} & \multicolumn{2}{|c|}{$(R)-8$} & \multicolumn{2}{|c|}{$(S)-8$} \\
\hline & & & $\begin{array}{l}\text { Yield } \\
{[\%]}\end{array}$ & $\begin{array}{l}e e[b] \\
{[\%]}\end{array}$ & $\begin{array}{l}\text { Yield } \\
{[\%]}\end{array}$ & $\begin{array}{l}e e[\mathrm{~b}] \\
{[\%]}\end{array}$ \\
\hline $\mathrm{C}_{6} \mathrm{H}_{5}$ & 99 & 97 & 82 & 99 & 77 & 98 \\
\hline $4-\mathrm{H}_{3} \mathrm{CC}_{1} \mathrm{H}_{4}$ & 98 & 78 & 82 & 98 & 75 & 78 \\
\hline $4-\mathrm{ClC}_{n} \mathrm{H}_{4}$ & 99 & 54 & 71 & 99 & 63 & 54 \\
\hline $3-\mathrm{C}_{6} \mathrm{H}_{5} \mathrm{OC}_{6} \mathrm{H}_{4}$ & 97 & 96 & 72 & 97 & 70 & 96 \\
\hline $3 \mathrm{O}, \mathrm{NC}_{4} \mathrm{H}_{4}$ & 89 & - & 81 & 87 & - & - \\
\hline $\mathrm{C}_{6} \mathrm{H}_{2} \mathrm{CH}_{2}$ & 74 & - & 90 & 74 & - & - \\
\hline$\left(-\mathrm{C}_{6} \mathrm{H}_{1}\right)$ & 99 & & 88 & 97 & $\cdots$ & - \\
\hline $3-\mathrm{BrC}_{4} \mathrm{H}_{4}$ & - & 92 & - & - & 76 & 90 \\
\hline $3-\mathrm{CK}_{n} \mathrm{H}_{+}$ & - & 91 & -- & $\cdots$ & 69 & 91 \\
\hline $3-\mathrm{H}_{3} \mathrm{COC}_{n} \mathrm{H}_{4}$ & - & 89 & - & - & 67 & 90 \\
\hline $\left.\mathrm{H}_{3} \mathrm{C}_{(\mathrm{CH}}\right)_{2}$ & 96 & - & 85 & 96 & - & \\
\hline $2-\mathrm{H}_{3} \mathrm{CS}\left(\mathrm{CH}_{2}\right)_{2}$ & 98 & & 87 & 98 & & - \\
\hline
\end{tabular}

[a] Crude product. [b] Determined by gas chromatography after formation of the isopropyl ester (treatment with $\mathrm{HCl}$-saturated isopropanol) and subsequent derivatization 10 the diastereomeric $(R)$-MTPA esters $[13,23]$.

Table 7. Acid-catalyzed hydrolysis of the $(R)$ ketone cyanohydrins $(R)-5$ and $(R)-6$ (prepared in situ by enzyme-catalyzed addition of HCN to ketones 3 and 4 , respectively) to $x$-hydroxycarboxylic acids $(R)-10$ and $(R)$-11, respectively [33].

\begin{tabular}{lllll}
\hline & & $(R)-5 .(R)-6$ & \multicolumn{2}{c}{$(R)-\mathbf{1 0},(R)-\mathbf{1 1}$} \\
$\mathrm{R}^{1}$ & $\mathrm{R}^{2}$ & $e e[\%]$ & Yield [\%] & ee [a] [\%] \\
\hline $\mathrm{C}_{2} \mathrm{H}_{5}$ & $\mathrm{CH}_{3}$ & 76 & 85 & 76 \\
$n \mathrm{C}_{3} \mathrm{H}$ & $\mathrm{CH}_{3}$ & 97 & 64 & 99 \\
$n \mathrm{C}_{4} \mathrm{H}_{4}$ & $\mathrm{CH}_{3}$ & 98 & 72 & 98 \\
$n \mathrm{C}_{5} \mathrm{H}_{11}$ & $\mathrm{CH}_{3}$ & 98 & 78 & 98 \\
$\left(\mathrm{H}_{3} \mathrm{C}\right)_{2} \mathrm{CH}$ & $\mathrm{CH}_{3}$ & 90 & 76 & 90 \\
$\left(\mathrm{H}_{3} \mathrm{C}\right)_{2} \mathrm{CHCH}$ & $\mathrm{CH}_{3}$ & 98 & 89 & 96 \\
$\left(\mathrm{H}_{3} \mathrm{C}_{2} \mathrm{CH}\left(\mathrm{CH}_{2}\right)_{2}\right.$ & $\mathrm{CH}_{3}$ & 98 & 88 & 99 \\
$n \mathrm{C}_{3} \mathrm{H}_{7}$ & $\mathrm{C}_{2} \mathrm{H}_{5}$ & 85 & 82 & 85 \\
$n \mathrm{C}_{4} \mathrm{H}_{4}$ & $\mathrm{C}_{2} \mathrm{H}_{5}$ & 90 & 89 & 90 \\
\hline
\end{tabular}

[a] Determined by gas chromatography on $\beta$-cyclodextrin columns after esterification with diazomethane [33].

diethyl ether, isolated, and characterized. Comparison of the optical purity of the crude cyanohydrins with that of the isolated and purified $\alpha$-hydroxycarboxylic acids shows hydrolysis to proceed virtually without racemization in all cases investigated (Tables 6, 7).

A wide spectrum of cyanohydrins is easily accessible by the enzymatic procedure outlined above. The acid-catalyzed hydrolysis of the optically active cyanohydrins, which can be conducted without racemization, thus represents a general route for the preparation of chiral $\alpha$-hydroxycarboxylic acids.

Optically active $\alpha$-hydroxy aldehydes are also important structural elements in natural products and thus might also be employed as chiral starting materials in asymmetric syntheses. ${ }^{[52]}$ Direct conversion of optically active cyanohydrins into the corresponding $\alpha$-hydroxy aldehydes would make this class of compounds easily accessible. Cyanohydrin racemates in fact have been hydrogenated with Raney nickel in acidic medium to $\alpha$-hydroxy aldehydes. ${ }^{[53 a]}$ When this procedure was extended to optically active cyanohydrins, the configuration of the isolated products indicated that hydrogenation occurs with a high degree of retention of configuration. ${ }^{[53 \mathrm{~b}]}$ Because of the moderate yields and the difficult product isolation, however, selective hydrogenation of $\alpha$-hydroxycarboxylic acids (see above) appears a much more favorable route to chiral $\alpha$-hydroxy aldehydes. ${ }^{\text {[52d. 54] }}$

Hydrogenation of chiral cyanohydrins to 2-amino alcohols is also of considerable preparative interest, since these compounds have a wide spectrum of biological activity. ${ }^{[5]}$ They may be categorized as adrenalin-type derivatives (amino function at a primary carbon atom) or ephedrin-type derivatives (amino function at a secondary carbon atom). Adrenalin-type 2-amino alcohols can be prepared from $\mathrm{O}$-protected chiral cyanohydrins by various hydrogenating procedures without any trace of racemization. ${ }^{[4 a, 43 a, 56]}$ Interestingly, free chiral cyanohydrins may also be hydrogenated directly and without racemization to the corresponding amino alcohols. ${ }^{[13 \mathrm{c}]}$ Here, as in the synthesis of $\alpha$-hydroxycarboxylic acids, the chiral cyanohydrins obtained from enzyme-catalyzed $\mathrm{HCN}$ addition in organic solvents can be applied directly, without any specific purification, for the hydrogenation process (Scheme 6. Table 8). ${ }^{[130]}$

Table 8. Hydrogenation of $(R)$ cyanohydrins $(R)$-2 (prepared in situ by enzyme-catalyzed addition of HCN to aldehydes 1$)$ with $\mathrm{LiAlH}_{4}$ to give amino alcohols $(R)-9$ $[13 \mathrm{c}]$.

\begin{tabular}{|c|c|c|c|c|c|c|c|}
\hline \multirow[t]{2}{*}{$\mathrm{R}$} & \multirow{2}{*}{$\begin{array}{l}(R)-2 \\
e \\
{[\%]}\end{array}$} & \multicolumn{2}{|c|}{$(R)-9$} & \multirow[t]{2}{*}{$\mathrm{R}$} & \multirow{2}{*}{$\begin{array}{l}(R)-2 \\
2 \% \\
{[\%]}\end{array}$} & \multicolumn{2}{|c|}{$(R)-9$} \\
\hline & & $\begin{array}{l}\text { Yield } \\
{[\%]}\end{array}$ & $\begin{array}{l}e^{\prime}[\mathrm{a}] \\
{[\%]}\end{array}$ & & & $\begin{array}{l}\text { Yield } \\
\text { [\%] }\end{array}$ & $\begin{array}{l}\%[a] \\
{[\%]}\end{array}$ \\
\hline $\mathrm{C}_{6} \mathrm{H}_{5}$ & 99 & 92 & 99 & $2-\mathrm{H}_{3} \mathrm{CS}\left(\mathrm{CH}_{2}\right)_{2}$ & 98 & 31 & 98 \\
\hline $3-\mathrm{C}_{6} \mathrm{H}_{5} \mathrm{OC}_{6} \mathrm{H}_{4}$ & 98 & 97 & 95 & $n \mathrm{C}_{3} \mathrm{H}_{7}$ & 96 & 99 & 89 \\
\hline $4-\mathrm{H}_{3} \mathrm{CC}_{6} \mathrm{H}_{4}$ & 99 & 100 & $>98$ & 2-furyl & 98 & 71 & 98 \\
\hline$c-\mathrm{C}_{6} \mathrm{H}_{11}$ & 91 & 94 & 80 & $\left(\mathrm{H}_{3} \mathrm{C}\right)_{3} \mathrm{C}$ & 93 & 70 & $>90$ \\
\hline
\end{tabular}

[a] Determined by gas chromatography on Chiracil-Val columns after conversion into the corresponding $(R)-\beta-N, O$-bis(trifluoroacetyl)amino alcohols by treatment with trifluoroacetic acid $[13 \mathrm{c}]$.

Preparation of 2-amino alcohols of the ephedrin type starting from cyanohydrins was first described by Krepski et al.; O-protected racemic cyanohydrins were reacted with Grignard reagents, and the resulting imino intermediates were subsequently hydrogenated with $\mathrm{NaBH}_{4} \cdot{ }^{[57]}$ This method was also applied successfully to $(R)$ and $(S)$ cyanohydrins. ${ }^{[58,59]}$ Investigation of the stereochemistry of this reaction for both $(R)$ and $(S)$ cyanohydrins established that the Grignard addition pro-
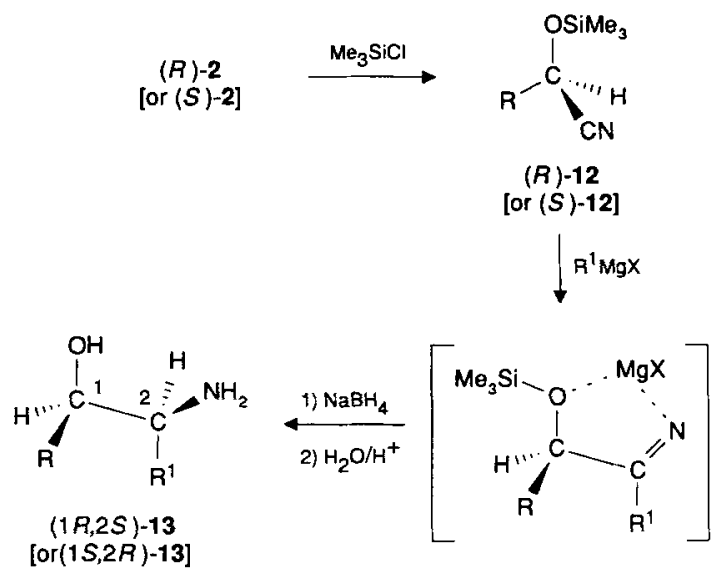

Scheme 8. Stereoselective synthesis of 2-amino alcohols. $\mathrm{R}=\mathrm{C}_{3} \mathrm{H}_{7}, \mathrm{C}_{6} \mathrm{H}_{5} ; \mathrm{R}^{\prime}=$ $\mathrm{CH}_{3}, \mathrm{C}_{2} \mathrm{H}_{5}, \mathrm{C}_{6} \mathrm{H}_{5} ; \mathrm{X}=\mathrm{Br}$, I 
ceeds without any racemization at $\mathrm{C}-1$. The hydrogenation at $\mathrm{C}-2$ is highly diastereoselective owing to chelate control; erytho products are formed almost exclusively (Scheme 8 . Table 9). ${ }^{[59]}$ On the other hand, the threo compounds are formed predominantly when $N$-diisobutylaluminum hydride is added to the O-protected cyanohydrin before the organolithium reagent is added. ${ }^{[60]}$ This procedure, however, is decidedly less diastereoselective. ${ }^{[60]}$

Table 9. Synthesis of 2-amino alcohols $(1 R, 2 S)$ - and $(1 S, 2 R)$-13 from the respective cyanohydrins $(R)$ - and $(S)-2$ (crude products) by formation of the trimethylsily ethers $(R)$-and $(S)-12$, Grignard reaction. and subsequenc hydrogenation of sodium borohydride [59].

\begin{tabular}{|c|c|c|c|c|c|c|c|c|}
\hline \multirow[t]{2}{*}{$\mathrm{R}$} & \multicolumn{2}{|c|}{ Cyanohydrin 2} & \multicolumn{6}{|c|}{ 2-Amino alcohol $(1 R .2 S)$ - or $(1 S .2 R)$-13 } \\
\hline & $\begin{array}{l}\% \% \\
1 \%]\end{array}$ & Config. & $\mathrm{R}^{1}$ & $\begin{array}{l}\text { Yield [a] } \\
{[\%]}\end{array}$ & $\begin{array}{l}e[\mathrm{~b}] \\
{[\%]}\end{array}$ & $\begin{array}{l}d e^{e}[\mathrm{~b}] \\
{[\%]}\end{array}$ & $\begin{array}{l}e \cdot c] \\
{[\%]}\end{array}$ & $\begin{array}{l}d e[c] \\
{[\%]}\end{array}$ \\
\hline $\mathrm{C}_{n} \mathrm{H}_{5}$ & $>99$ & $(R)$ & $\mathrm{C}_{6} \mathrm{H}_{5}$ & 83 & 99 & 99 & 100 & 100 \\
\hline $\mathrm{C}_{6} \mathrm{H}_{5}$ & $>99$ & $(R)$ & $\mathrm{C}_{2} \mathrm{H}_{5}$ & 53 & 97 & 94 & $>99$ & $>99$ \\
\hline $\mathrm{C}_{6} \mathrm{H}_{5}$ & $>99$ & $(R)$ & $\mathrm{CH}_{3}$ & 50 & 99 & 92 & 99 & $>90$ \\
\hline $\mathrm{C}_{3} \mathrm{H}_{7}$ & 95 & $(R)$ & $\mathrm{C}_{6} \mathrm{H}_{5}$ & 93 & 92 & 93 & $>99$ & $>99$ \\
\hline $\mathrm{C}_{3} \mathrm{H}_{7}$ & 95 & $(R)$ & $\mathrm{CH}_{3}$ & 44 & 93 & 63 & - & 63 \\
\hline $\mathrm{C}_{6} \mathrm{H}_{s}$ & $>99$ & $(S)$ & $\mathrm{C}_{6} \mathrm{H}_{5}$ & 95 & 99 & 99 & 100 & 100 \\
\hline $\mathrm{C}_{6} \mathrm{H}_{5}$ & $>99$ & $(5)$ & $\mathrm{CH}_{3}$ & 66 & 99 & 90 & $>99$ & $>99$ \\
\hline
\end{tabular}

[a] As the hydrochloride. [b] Determined by gas chromatography after treatment of the crude products with pivaloyl chloride and filtration through silica gel [c] Determined after one recrystallization.

In both hydrogenation ${ }^{[61 \mathrm{a}]}$ and Grignard reaction ${ }^{[61 \mathrm{~b}]}$ with $O$-protected cyanohydrins, imines are formed initially; these may be subjected to transimination with primary amines to furnish biologically interesting $\mathrm{N}$-substituted amino alcohols. Addition of $\mathrm{HCN}$ to the imino compounds affords $\beta$-hydroxy $\alpha$-amino acids stereoselectively, if one starts out with a chiral cyanohydrin. ${ }^{[62]}$ Hydrolysis of the imino compounds formed by addition of Grignard reagents to $O$-protected chiral cyanohydrins yields optically active acyloins. ${ }^{[18 a}$. 63]

\subsection{Reactions of the Hydroxyl Group}

The synthetic potential of optically active cyanohydrins can be extended tremendously if the $\mathrm{OH}$ group is converted into a good leaving group which may be exchanged stereoselectively with a wide range of nucleophiles. ${ }^{[6]}$ Nucleophilic substitution reactions with activated $\alpha$-hydroxycarboxylic acids and esters are well established, ${ }^{[514.65]}$ but little is known about the analogous reactions of $x$-hydroxynitriles. ${ }^{[66]}$ So far only $x$ halonitriles have been prepared in optically pure form. ${ }^{160]}$ The halide ion released upon reaction of these compounds is a good nucleophile and leads to partial racemization of the chiral $\alpha$ halonitriles during nucleophilic substitution. ${ }^{[66]} \alpha$-Sulfonyloxynitriles $(R)-14$, which are easily accessible from chiral cyanohydrins $(R)-2$ by sulfonylation, have a much higher configurational stability than the $\alpha$-halonitriles (Scheme 9) ${ }^{[64]}$ $x$-Sulfonyloxynitriles derived from aliphatic cyanohydrins are considerably more stable than those from aromatic cyanohydrins. ${ }^{[64]}$ Under mild conditions aliphatic $\alpha$-sulfonyloxynitriles $(R)$-14 react with nucleophiles with complete inversion of configuration; the aromatic analogues react with weak nucleophiles with at least partial racemization. ${ }^{64]}$
Nucleophilic substitution of optically active $\alpha$-sulfonyloxynitriles $(R)-14$ allows access to a great variety of interesting compounds, such as $\alpha$-azidonitriles $(S)$-15, $\alpha$-aminonitriles $(S)$ 16. $x$-amino acids $(S)$-17, and aziridines $(S)$-18 in optically pure form (Scheme 9). ${ }^{[64]}$ Aliphatic cyanohydrins $(S)$-2, which are not accessible by the $(S)$-oxynitrilase-catalyzed addition of HCN to aldehydes, ${ }^{[23.24]}$ may be prepared by $\mathrm{S}_{\mathrm{N}} 2$ reactions of the stable $(R)$ 2-sulfonyloxynitriles $(R)-14$ with acetates. ${ }^{[64 \mathrm{~b}]}$ The resulting cyanohydrin esters $(S)-19$ then are hydrolyzed to the cyanohydrins $(S)-\mathbf{2}$.
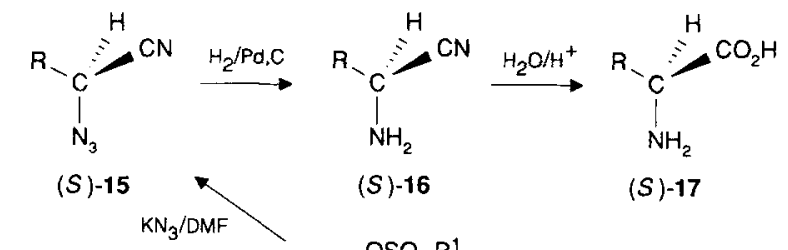

(S)-16

(S)-17

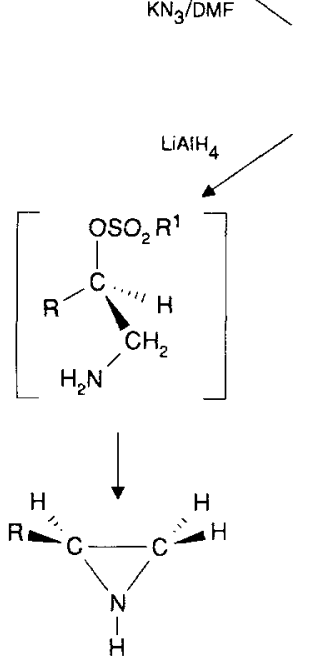

(S) -18

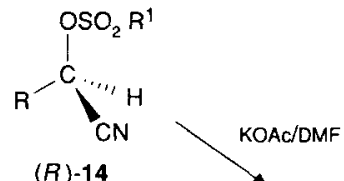

(R) -14

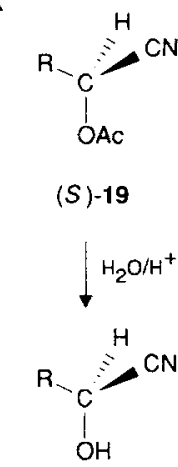

(S) -2
Scheme 9 . Stereoselective reactions of sulfonyl-activated $(R)$ cyanohydrins with nucleophiles with inversion of configuration. $\mathrm{R}^{1}=\mathrm{CH}_{3}, \mathrm{CF}_{3}, 4-\mathrm{CH}_{3} \mathrm{C}_{6} \mathrm{H}_{4}$

Sulfonyl-activated cyanohydrins are often employed in synthesis, since both the cyanohydrin and the nucleophile can be varied. In addition, direct stereoselective reactions of the cyanohydrin $\mathrm{OH}$ group are also feasible with special reagents. $(S)$ Fluoronitriles $(S)$-20, for instance, may be prepared directly and in good optical yield from the $(R)$ cyanohydrins $(R)-2$ by reaction with diethylaminosulfur trifluoride (DAST). ${ }^{[67]}$ These $\alpha$-fluoronitriles $(S)$-20 then are hydrolyzed to the $x$-fluorocarboxylic acids (S)-21 without notable racemization (Scheme 10) ${ }^{[67]}$

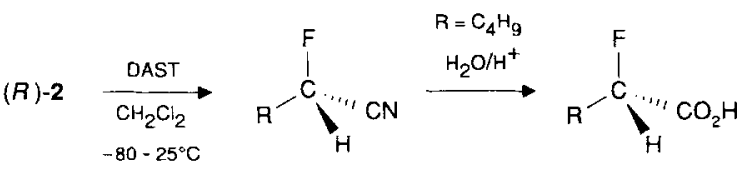

(S) -20

(S) -21

$$
\mathrm{R}=\mathrm{C}_{3} \mathrm{H}_{7}, \mathrm{C}_{4} \mathrm{H}_{9},\left(\mathrm{H}_{3} \mathrm{C}_{2} \mathrm{CHCH}_{2}, c-\mathrm{C}_{6} \mathrm{H}_{11}, \mathrm{C}_{6} \mathrm{H}_{5}\right.
$$

Scheme 10. Preparation of $(S)$ 2-fluoronitriles and $(S)$-2-fluorocarboxylic acids from $(R)$ cyanohydrins. 
Another example of a stereoselective reaction in this context is the Mitsunobu reaction of optically active cyanohydrins in the presence of carboxylic acids, which takes place with inversion of configuration, thus permitting preparation of $(S)$ cyanohydrins directly from their $(R)$ isomers. ${ }^{[68]}$

\section{Summary and Outlook}

The enzyme-catalyzed asymmetric synthesis of cyanohydrins known for close to ninety years has only in the last decade turned into an important instrument for organic synthesis. The markedly improved enantioselectivities are possible primarily by suppression of the chemical cyanohydrin formation. This can be achieved either by employing an organic solvent or by working at low $\mathrm{pH}$ values.

( $R$ ) Cyanohydrins in particular have become easily accessible by this procedure, and their considerable synthetic potential as $x$-substituted carboxylic acid derivatives has been firmly established within a few years. Reactions of optically active cyanohydrins can be conducted with retention of chirality, and further stereogenic centers can be introduced diastereoselectively. Thus chiral cyanohydrins open up routes to other important classes of compounds with stereogenic centers. The synthetic potential of chiral cyanohydrins appears particularly important for the diastereoselective synthesis of drugs with stereogenic centers. Even if drugs like 2-amino alcohols are still applied in racemic form today, all stereoisomers are required for registration, since the activity spectrum and metabolism of each isolated stereoisomer must be established. Chiral cyanohydrins frequently open simple and direct routes to the individual stereoisomers.

The $(R)$-oxynitrilase from bitter almonds has a broad substrate spectrum and can be obtained readily in industrial quantities. In contrast, the substrate spectrum of $(S)$-oxynitrilase from Sorghum is restricted mainly to aromatic aldehydes, and the poor availability of this enzyme is more or less prohibitive for industrial applications. Future developments in the synthesis of optically active cyanohydrins are thus expected primarily in extending the substrate spectrum of $(S)$-oxynitrilases and in improving their availability. $(S)$-oxynitrilases from other organisms (plants, insects) may extend and improve the substrate spectrum. The poor accessibility of $(S)$-oxynitrilases, however, will be overcome only by cloning and overexpression in a sufficiently efficient production organism.

Modification of the active center(s) of the oxynitrilases, which is prerequisite for further optimization of the substrate selectivity, requires knowledge of the complete enzyme structure. Currently, little or rather almost nothing is known about the threedimensional structure of oxynitrilases. If this deficit can be overcome, oxynitrilases will gain even more importance in the synthesis of chiral compounds.

The enthusiastic commitment of my co-workers, who are cited in the references, has helped to bridge the gap between organic sl?nthesis and enzymology which has been decisive for our successful exploitation of chiral cyanohydrins in synthesis. My special gratitude is due to Drs. Thomas Ziegler and Siegfried Förster who played a major role from the beginning in the development of the work described in this review. Dr. Angelika Baro was strongly engaged in the drafting of this article, for which I am very grateful. Generous financial support of this work by the Bundesministerium für Forschung und Technologie (BMFT) under the auspices of the "Zentrales Schwerpunktprogramm Bioverfahrenstechnik Stuttgart" is gratefully acknowledged, as is the constant support by the Fonds der Chemischen Industrie.

\author{
Received: October 25. 1993 [A 33 IE] \\ German version: Angew. Chem. 1994, 304,1609
}

[1] a) F. Effenberger, NATO ASI Ser. Ser. C 1992. 381.25 33 [Chem, Abstr. 1993. 118. 254088v]; b) F. Effenberger in Enzlme Catalysis in Organic Stnhthesis (Eds. : K. Drauz. H. Waldmann), VCH. Weinheim, in press.

[2] a) C. G. Kruse, J. Brussee, A. van der Gen, Sper. Chem. 1992, 12. 184 192 [Chem. Abstr. 1992, 117, 150273q]; b) C. G. Kruse. H. W. Getuk. G. J. M. van Scharrenburg. Chim. Oggi 1992, 10,59-63 [Chem. Abstr. 1992, 117,113935m]: c) C. G. Kruse in Chirality in Industry (Eds.: A. N. Collins, G. N. Sheldrake, J. Crosby), Wiley. New York, 1992, pp. 279-299.

[3] W. R. Jackson. H. A Jacobs, G. S. Jayatiake, B. R. Matthews, K. G. Watson, Aust. J. Chem. 1990, 43, $2045-2062$.

[4] a) J. D. Elliott, V. M. F. Choi. W. S. Johnson, J. Org. Chem. 1983, 48. 2294 2295: b) M. T. Reetz. M. W. Drewes, K. Harms. W. Reif. Teirahedron L'tt. 1988. 29. 3295-3298; c) M. T. Reetz. M. W. Drewes. A. Schmitz. X. Holdgruen, T. Wuensch. J. Binder, Philos. Trans. R. Soc. Londom A 1988. 326, 573-578 [Chem. Abstr. 1989, 111, 77550x].

[5] a) R. Herranz, J. Castro-Pichel, T. Garcia-Lopec, Synthesis 1989, 703 - 706: b) J. L. Garcia Ruano, A. M. Martin Castro, J. H. Rodriguez. Tetrahedron Lett. 1991, 32, 3195-3198.

[6] a) M. Hayashi. T. Matsuda, N. Oguni, J. Chem. Soc. Chem. Commun. 1990. $1364-1365$; b) M. Hayashi. T. Matsuda, N. Oguni. J. Chem. Ser. Perkin Trans. 1. 1992. 3135-3140: c) M. Hayashi, Y. Miyamoto, T. Inoue, N. Oguni. J. Org. Chem. 1993, 58, 1515-1522; d) K. Narasaka. T. Yamada, H. Minamikawa, Chem. Lett. 1987. 2073 2076; e) H. Minamikawa, S. Hayakawa, T. Yamada, N. Iwasawa, K. Narasaka, Bull. Chem. Soc. Jpn. 1988, 61. 4,379-4383.

[7] a) H.-J. Altenbach in Organic Synthesis Highlights (Eds.: J. Mulzer, H.-J. Altenbach, M. Braun, K. Krohn, H.-U. Reissig), 1991, pp. 66-70: b) D. M. Dalton. C. M. Garner, J. M. Fernández, J. A. Gladysz, J. Org Chem. 1991. 56, 6823-6829; c) S. Kobayashi, Y. Tsuchiya, T. Mukaiyama, Chen. Len. 1991. $541-544$; d) E. J. Corey, Z. Wang. Tetrahedron Lett. 1993, 34, 4001 - 4004.

[8] a) J. Oku. N. Ito, S. Inoue, Makromol. Chem. 1979. 180.1089-1091; b) J. Oku. S. Inoue, f. Chent. Src Chemz. Commun. 1981.229-230; c) M. North. Symlett 1993, $807-820$.

[9] L. Rosenthaler, Biochem. Z. 1908, 14, 238-253.

[10] a) V. K. Krieble. W. A. Wieland, J. Am. Chcm. Soc. 1921, 43. 164-175; b) H. Albers. K. Hamann, Biochem. Z. 1932. $255,44-65 ; c)$ H. Albers. K. Hamann, ibid. 1934, 269, 14-25.

[11] a) W. Becker, U. Benthin, E. Eschenhof, E. Pfeil, Biochum. Z. 1963,337, 156 $166 ;$ b) W. Becker. E. Pfeil. ibid. 1966. 346, $301-321$

[12] a) W. Becker. H. Freund, E. Preil, Angen. Chem. 1965. 77, 1139: Angen. Chem. Int. Ed. Engl. 1965. 4, 1079; b) W. Becker. E. Pfeil, J. Am. Chem. Soc. 1966, 8s, 4299.4300 ; c) E. Pfeil. W. Becker, DE-B 1300111,1969 [Chem. Ahstr. 1970, 72, P3061 1 ]

[13] a) F. Effenberger, T. Ziegler, S. Förster, Angew, Chem. 1987, 99, 491-492; Angew. Chem. Int. Ed. Engl. 1987, 26,458-460; b) F. Effenberger. T. Ziegler. S. Förster (Degussa AG). DE-B 3701383, 1988 [Chem. Abstr. 1989, 110, 74845 r]; c) T. Ziegler, B. Hörsch, F. Effenberger, Simhesis 1990, 575578.

[14] a) C. Laque, J. Tramper, M. D. Lilly, Biocatallsis in Organic Media, Studies in Organic Chemistry, vol. 29, Elsevier, Amsterdam, 1987; b) S. Fukui, A. Tanaka. Endeavou 1985, 9, 10 - 17 [Chem. Abstr. 1985, 103,33788m]; c) A. M. Klibanov. Acc. Chem. Res. 1990. 23, 114-120; d) K. R. Nalarajan. J. Chem. Educ. 1991, 68, 13-16; e) K. Faber. Biotransformations it Organic Simthesis. Springer, Berlin, 1992, pp. $248-282$.

[15] a) F. Effenberger. B. Spachmann. S. Förster. B. Bauer, I. Wonner, unpublished results; b) B. Bauer, H. Strathmann, F. Effenberger. DE-B 4041 896. 1991 [Chem. Abstr. 1992, 116, 150138d].

[16] E. Wehtje. P. Adlercreutz. B. Mattiasson, Biotechnol. Biong. 1990, 36, 39-46.

[17] a) U. Kragl, U. Nieúermeyer. M.-R. Kula, C. Wandrey, Ann. N. Y. Accit. Sci. 1990, 613,167-175 [Chem. Abstr. 1991, 115,181477x]: b) U. Niedermeyer, U. Kragl. M.-R. Kula, C. Wandrey, K. Makryaleas, K. Drauz (Degussa AG), Eur. Pat. Appl. EP 0326063 A2, 1989 [Chem. Abstr. 1990, 1t? 234012p].

[18] a) J. Brussee. E. C. Roos, A. van der Gen, Tetrahutron Le't 1988, 20, 4485 4488: b) J. Brussee, W. T. Loos. C. G. Kruse, A. van der Gen, Tetrahedron 1990. 46. 979-986; c) P. Zandbergen. J. van der Linden. J. Brussee. A. van der Gen. Sinth. Commun. 1991, 21, 1387-1391.

[19] a) V. I. Ognyanov, V. K. Datcheva, K. S. Kyler, J. Am. Chom. Soc 1991, 113, 6992 6996; b) T. T. Huuhtanen, L. T. Kanerva, Tetrahedron Astmmetry 1992. 3. $1223-1226$.

[20] F. Effenberger, J. Eichhorn, unpublished results 
[21] a) C. Bove. E. E. Conn. J. Biol. Chem. 1961, 236, 207-210; b) M. K. Seely, R. S. Criddle, E. E. Conn, ibid. 1966, 241. 4457-4462.

[22] a) I. Jansen. R. Woker. M.-R. Kula. Biotechnol. Appl. Biochem. 1992, 15, 90 99: b) H. Wajant. K.-W. Mundry. Plant Sci. Limerick Irel. 1993.89.127 133 c) E. Smitskamp-Wilms. J. Brussee, A. van der Gen, G. J. M. van Scharrenburg. J. B. Sloothak. Rect. Trar. Chim. Pats-Bas 1991, 110. 209.215.

[23] F. Effenberger. B. Hörsch. S. Förster, T. Ziegler, Tetrahe'dron Lan. 1990, $3 t$ 12491252

[24] U. Niedermeyer. M.-R. Kula. Angew, Chem. 1990, 102, 423 -424: Angew Chem. Int. Ed. Engl. 1990. 29,386 387 .

[25] N. Klempier, H. Griengl. M. Hayn, Tetrahetron Lett. 1993, 34, 4769-4772.

[26] a) S. Förster. F. Effenberger, unpublished results; b) H. Wajanı. H. Böttinger. K.-W. Mundry. Biolechnol. Appl. Biochem. 1993. f8. 75-82

[27] D. A. Livingston. J. E. Petre. C. L. Bergh. J. Am. Chem. Soc 1990, 1/2, 6449. 6450

[28] N. S. Batra, E. Brunet, Fordhedrom Lett. 1993, 34.711-714

[29] J. L. Garcia Ruano. A. M. Martin Castro. J. H. Rodriguez. J. Org. Chom. 1992. $57.7235-7241$.

[30] M. T. Reet7. K. Kesseler. A. Jung. Angen, Chem. 1985, 97. 989 .. 990: Angen Chom. Int. Ed. Engl. 1985, 24,989-990.

[31] H. Ohta, Y. Kimura, Y. Sugano. T. Sugai, Tetrahedron 1989, 45, 5469. 5476.

[32] A. Nahrstedt. Biol. Linserer Zeit 1988, 18,105 109

[33] a) F. Effenberger. B. Hörsch. F. Weingart, T. Ziegler, S. Kühner, Tetrahedron Lett. 1991, 32, 2605. 2608: b) S. Heid, Diplomarbcit. Universität Stuttgart. 1991.

[34] a) J. Oku. N. Ito. S. Inoue, Makromol. Chom 1982, 183, 579 586: b) A. Mori. Y. Ikeda, K. Kinoshita, S. Inoue, Chem. Lett. 1989. 2119 2122: c) K. Tanaka, A. Mori. S. Inoue, J. Org. Chem. 1990. 55, $181 \ldots 185$.

[35] a) S. Asada, Y. Kobayashi, S. Inoue, Makromol. Chem. 1985, $186.1755 \cdot 1762$ b) Y. Kobavashi. S. Asada, I. Watanabe, H. Hayashi. Y. Motoo. S. Inoue, Bull. Chem. Soc. Jpn. 1986. 59.893 895.

[36] a) W. R. Jackson. G. S. Jayatilake. B. R. Matthews. C. Wilshire, Aust. J. Chem 1988. 4t, $203-213$; b) B R Matthews, W. R. Jackson, G S Jayatilake. C. Wilshire, H. A. Jacobs, ihid. 1988, 41, $1697 \cdots 1709$; c) W. Dong, W. L. Petty (Shell Oil Co.). US-A 535500, 1983 [Chem. Ahstr. 1985, /03, 196420z].

[37] a) H. Danda, H. Nishikawa, K. Otaka, J. Org. Chem. 1991. 56, 6740 6741 b) H. Danda. Sinlett 1991, 263-264; c) S. D. Rychnovsky, Chemeracts: Org. Chem. 1992. 5, 102 105 [Chem. Ahstr. 1992.117.150608c]

[38] K. Naumann. Chemistry of Plant Protection. 5: Synthetic Pyethroid Insecticides: Chemistry and Patents, Springer, Berlin, 1990. pp. 110. 141.

[39] a) M. North, Tetrahedrof 1992, 48.5509-5522; b) D. Callant. B. Coussens, T v. d. Maten. J. G. de Vries. N. Koen de Vries. Tetrahedron Asvmmetry 1992, 3 $401-414$ : c) H. J. Kim. W. R. Jackson, ibit. 1992、3, 1421-1430; d) D. J. P. Hogg. M. North. Tetrahedron 1993.49.1079 1090

[40] a) A. Mori. H. Ohno. H. Nitta, K. Tanaka. S. Inoue. Sinlett 1991, 563564 b) H. Ohno. H. Nitta, K. Tanaka. A. Mori. S. Inoue, J. Org. Chem. 1992.57. $6778 \cdot 6783$

[41] F. Effenberger. B. Gutterer, T. Ziegler, E. Eckhardt. R. Aichholz. Liebigs Am. Chem. 1991, 47 54, and references therein

[42] a) N. Matsuo, N. Ohno, Tetruhedron Letl. 1985, 26, 5533 5534; b) A. van Almsick. J. Buddrus. P. Hönicke-Schmide, K. Laumen, M. P. Schneider, J Chem. Soc. Chem. Commun. 1989,1391-1393.

[43] a) H. Ohta. Y. Miyamae, G. Tsuchihashi. Agric. Biol. Chem. 1986, 50, 3181 3184: ihid. 1989. 53. 215-222: b) H. Hirohara, S. Mitsuda, E. Ando. R. Komaki, Stud. Org. Chem. (Amsterdam) 1985, 22, 119-134.

[44] a) Y. F. Wang. S. T. Chen. K. K. C. Liu. C. H. Wong. Tetrahedron Lett. 1989 30. 1917-1920: b) S. H. Hsu. S. S. Wu. Y. F. Wang. C. H. Wong, ibid, 1990, 31 , $6403-6406$

[45] a) M. Inagaki, J. Hiratake. T. Nishioka. J. Oda, J. Am. Chem. Soc 1991. 1/3. 9360-9361: b) M. Inagaki. A. Hatanaka. M. Mimura. J. Hiratake. T. Nishioka, J. Oda, Bull. Chem. Soc. Jpn. 1992, 65, 111-120; c) M. Inagaki, J. Hiratake. T. Nishioka, J. Oda, J. Org. Chem. 1992. 57. $5643 \cdots 5649$
[46] H. S. Bevinakatti, A. A. Banerji, R. V. Newadkar, J. Org. Chem. 1989. 54. $2453-2455$.

[47] a) D. A. Evans. M. M. Morrissey, R. L. Dorow. J. Am. Chem. Soc. 1985, 107. 43464348 ; b) H. C. Brown. J. Chandrasekharan, P. V. Ramachandran, J Org. Chem. 1986, 5t, 3394-3396; c) E. J. Corey, J. O. Link. Tetrahedron Lett. 1992. 3.3. 3431 -3434; d) K. Mikami. M. Terada. T. Nakai. J. Am. Chem. Soc 1990. $1 / 2.3949 \cdot 3954$

[48] a) S. Servi. Sinhesis 1990, 1 25; b) S. Tsuboi. E. Nishiyama, H. Furutani, M. Utaka. A. Takeda, J. Org. Chem. 1987,52,1359-1362.

[49] i) M.-J. Kim. (i. M. Whitesides, J. Am. Chum. Soc. 1988. 1f0, 2959 2964 b) M.-R. Kula, C. Wandrey, Mothods En-1mol. 1987, 136.9-21: c) M.-J. Kim, J. Y. Kim. J. Chom. Soc. Chem. Commun. 1991. 326-327.

[50] a) P. Katkartitis, R. W. Regenye, J. J. Partridge, D. L. Coffen. J. Org. Chem 1990. $55.812-815$ : b) T. Sugai, H. Ohta, Tetrahedron Lett. 1991, 32.7063-7064.

[51] a) U. Burkard. F. Effenberger. Chem. Ber. 1986, 119. 1594-1612; b) H. Kunz H-G. Lerchen, Teirahedion L't! 1987, 28, 1873-1876.

[52] a) S. K. Massad, L. D. Hawkins, D. C. Baker, J. Org, Chem. 1983, 48, $5180-$ 5182 ; b) J.R. Schwark. D. Hoppe. Sinthesis 1990, 291-294; c) Y. Kobayashi. M. Takase. Y. I10. S. Terashima. Bull. Chtm. Sol Imm. 1989,62, $3038 \cdot 3040$ d) M. Larcheveque, Y. Petit, Bull. Soc. Chim. Fr. 1989. 130-139; e) E. J. Corey G. B. Jones. Te'trahedron Lett. 1991. 32. 5713-5716.

[53] a) W. Althoff. R. Karsdorf. P. Tinapp. Anh. Phom. (Weinhein Ger., 1981 $314,518-524$; b) B. R. Matthews, H. Gountzos. W. R. Jackson, K. G. Watson. Tetrahetron Lett. 1989. 30, 5157.5158.

[54] F. Elfenberger. M. Hopf. T. Ziegler, J. Hudelmayer. Chem. Ber. 1991. 124. $1651-1659$.

[55] a) J. Engel, Chem-Zig. 1982. 106. 169-183; b) A. Kleemann, J. Engel, Phar ma-eutische Wirkstoffe Sinthesen. Patente, Anwendungen, 2nd ed. Thieme. Stutgart, 1982. and 1987 supplement; c) E. J. Corey. J. O. Link. Tetrahedron Lett. 1990. 31.601-604: d) J. Org. Chem. 1991. 56.442-444: e) M. T. Reetz M. W. Drewes. A. Schmitz. Angen: Chem. 1987.99.1186 1188: Angen. Chem Int. Ed. Engl. 1987, 26, 1141 1143; f) M. T. Reetz. M. W. Drewes, K. Lcnnick. A. Schmitz, X. Holdgrün, Tetrahedron Astmmetry 1990. 1. 375.378; g) T Ishizuka, S. Ishibuchi. T. Kunieda, Tetrahedron 1993, 49, 1841 -1852.

[56] N. Matsuo, N. Ohno. Tetrahedron Lett. 1985, 26, 5533-5534.

[57] L. R. Krepski. K. M. Jensen, S. M. Heilmann. J. K. Rasmussen, Sintheris 1986, 301303

[58] a) J. Brussee. F. Dofferhoff. C. G. Kruse, A. van der Gen, Tetrahedion 1990, 46 1653-1658; b) W. R. Jackson. H. A. Jacobs, B. R. Matthews. G. S. Jayatilake. K. G. Watson, Tetrahedron Letl. 1990. 31.1447-1450.

[59] F. Effenberger. B. Gutterer. T. Ziegler, Liehigs Ann. Chem. 1991. 269273

[60] G. Cainelli, E. Mezzina, M. Panunzio, Tetrahedron Lett. 1990, 31, 3481 3484

[61] a) P. Zandbergen. A. M. C. H. van den Nieuwendijk, J. Brussee, A. van der Gen. Tetrahedron 1992. 48, 3977. 3982; b) J. Brussee, A. van der Gen. Rect. Tral. Chim. Pars-Bas 1991, 110, 25-26.

[62] P. Zandbergen, J. Brussee. A. van der Gen. C. G. Kruse. Tetrahedron Aslmmetr. 1992, 3. 769774

[63] J. Brussee, R. A. T. M. van Benthem. C. G. Kruse, A. van der Gen. Tetrahedron As!mmely. 1990, $1,163-166$.

[64] a) F. Effenberger, U. Stelzer. Angen. Chem 1991, 103, 866-867; Angew: Chem Int. Ed. Engl. 1991, 30. 873. 874: b) F. Effenberger, U. Stelzer, Chem. Ber $1993,126,779,786$.

[65] a) F. Eftenberger, U Burkard. J. Willfahrt, Liebigs Ann. Chem 1986, 314333 b) U. Azzena. G. Delogu, G. Melloni. O. Piccolo, Tetrahedron Lett. 1989, 30 4555 - 4558: c) P. R. Fleming. K. B. Sharpless. J. Org. Chem. 1991, 56. 2869 2875 .

[66] a) I. A. Smith, Ber. Dtsch. Chem. Ges. B 1938, 71,634-643: b) K. Ichimura, M Ohta, Bull. Chem. Soc. Jpn. 1970, 43, 1443-1450.

[67] U. Stelzer, F. Effenberger. Tetrahedron Asymmetr 1993, 4, 161-164

[68] E. G. J. C. Warmerdam. J. Brussee, C. G. Kruse, A. van der Gen, Tetrahedron 1993. 4\%. $1063-1070$ 